Mateusz Potoczny, Metodologia nauczania języka syryjskiego w Ekumenicznym Instytucie Badawczym św. Efrema w Kottayam (Indie) (komunikat), [w:] Starożytność chrześcijańska. Materiały zebrane, red. Józef Cezary Kałużny, t. 4, Kraków 2016, s. 243-245.

DOI: http://dx.doi.org/10.15633/9788374385282.15

\title{
Mateusz Potoczny
}

WYDZIAŁ TEOLOGICZNY UNIWERSYTETU OPOLSKIEGO

\section{Metodologia nauczania języka syryjskiego w Ekumenicznym Instytucie Badawczym św. Efrema w Kottayam (Indie) (komunikat)}

Język syryjski dotarł do Indii na długo przed chrześcijaństwem. Już w starożytności był on bowiem używany jako lingua franca przybywających na subkontynent indyjski kupców ${ }^{1}$. Jednakże w świadomości miejscowej ludności tak naprawdę zakorzenił się dopiero po przybyciu wyznawców Chrystusa. Według tradycji ojcem indyjskiego chrześcijaństwa był św. Tomasz Apostoł, który po dotarciu do wybrzeży dzisiejszego stanu Kerala (52 rok) założył siedem Kościołów i po niemal 20 latach służby poniósł śmierć męczeńską (72 rok) w Mylapore, nieopodal dzisiejszego miasta Ćennaj w stanie Tamil $\mathrm{Nadu}^{2}$. Choć nie ma dokumentów historycznych potwierdzających rodzaj celebrowanej przez protowspólnotę liturgii, domniemywa się, że - mając tak wczesne korzenie - nie mogła wiele różnić się od tej sprawowanej w Jerozolimie. Jak przyjmują współcześni potomkowie i dziedzice tej czcigodniej tradycji, wraz z pierwszymi misjonarzami do Indii dotarł też dialekt języka aramejskiego - syryjski, stając się na długie wieki głównym językiem tamtejszego Kościoła³. Obecność syryjskiego umocniona została przez ścisły

\footnotetext{
1 X. Koodapuzha, Oriental churches. An introduction, Kottayam 1996, s. 42.

2 Więcej na temat Tomaszowej tradycji w Indiach zob.: P. Pallath, La Chiesa cattolica in India, Roma 2003; J. W. Żelazny, The tradition of St. Thomas' mission to India in the light of patristic studies, „Orientalia Christiana Cracoviensia” 3 (2011), s. 165-172.

3 P. Pallath, La Chiesa cattolica..., dz. cyt., s. 25.
} 
związek liturgiczno-hierarchiczny, jaki już w starożytności połączył Kościół indyjski z perskim patriarchatem w Seleucji-Ktezyfonie.

Dla indyjskich chrześcijan ów język, nazywany przez nich dumnie leshono d-moran ishu' mshio (,język naszego Pana Jezusa Chrystusa”), był zawsze skarbem pielęgnowanym z niezwykłą pieczołowitością. Mimo wprowadzenia do liturgii języków narodowych (głównie malajalam) indyjska troska o zachowanie syryjskiego dziedzictwa nie zanikła.

Jedną z instytucji stojących na straży wiernego zachowania i kontynuowania apostolskiej tradycji związanej z dziedzictwem języka syryjskiego jest powołany w 1985 roku Ekumeniczny Instytut Badawczy św. Efrema (St. Ephrem Ecumenical Research Institute, SEERI) z siedzibą w Kottayam. Będący pod pieczą katolickiej syro-malankarskiej archidiecezji Tiruvalla ośrodek ten współpracuje na płaszczyźnie naukowej ze wszystkimi Kościołami, zwłaszcza z tymi, które dzielą starożytne dziedzictwo syryjskie. Bogata biblioteka wraz ze zgromadzonymi mikrofilmami, manuskryptami i specjalistyczną literaturą syrologiczną (źródłową i opracowaniami) czyni z Instytutu prawdziwe betharke języka i liturgicznego dziedzictwa syryjskiego.

Instytut prowadzi szeroko zakrojone badania, których wyniki publikowane są głównie w serii wydawniczej Mōrān 'Ethō oraz w periodyku „The Harp". Ponadto SEERI jest organizatorem wielu seminariów i konferencji, z których najważniejszą jest organizowana co cztery lata konferencja międzynarodowa, przyciągająca najważniejszych przedstawicieli studiów syryjskich z całego świata.

Na szczególną uwagę zasługuje jednak dydaktyczna działalność placówki. Przede wszystkim jest to jedyna w Indiach uczelnia pozwalająca uzyskać państwowy certyfikat znajomości języka syryjskiego firmowany przez Mahatma Ghandi University. Studia zorganizowane są na kilku poziomach: trzymiesięczny kurs certyfikatu, dwuletnie studia magisterskie (M.A.) oraz studia doktoranckie (Ph.D.)4.

Podstawę metodologiczną początkowego stadium nauki stanowi wprowadzenie do języka syryjskiego autorstwa prof. Sebastiana Brocka. Następnie, w zależności od grupy, wprowadzane są kolejno podręczniki i gramatyki: G. A. Kiraz, The new Syriac primer. An introduction to the Syriac language, Piscataway 2007; J. Healey, First studies in Syriac, Piscataway 2005; W. M. Thackston, Introduction to Syriac. An elementary grammar

${ }_{4}$ J. Thekeparampli, SEERI, [w:] Dizionario enciclopedico dell'Oriente cristiano, ed. E. G. Farrugia, Roma 2000, s. 681. 
with readings from Syriac literature, Bethesda (Maryland) 1999; L. Costaz, Grammaire Syriaque, Bejrut 2003; i inne (w tym kilka podręczników w języku malajalam).

Plan studiów zakłada naukę gramatyki, syntaksji, fleksji, słownictwa etc. Sylabus przewiduje następujące działy nauczania: poezja, literatura liturgiczna, historia literatury syryjskiej, lingwistyka języka syryjskiego, literatura monastyczna, literatura na temat Tomasza Apostoła, literatura świecka, historia Kościoła, gramatyka, literatura biblijna, współczesność języka syryjskiego i inne.

Praktyki studenci nabywają, tłumacząc teksty ojców syryjskich oraz różnych liturgii należących do wschodniej i zachodniej tradycji syryjskiej. Całokształt studiów moderowany jest przez zespół specjalistów na czele $\mathrm{z}$ dyrektorem SEERI, ks. dr. Jakubem Thekeparampilem (zob. http://seeri. org/committee.html), wspomaganym przez szereg profesorów zapraszanych z zagranicy.

Egzamin końcowy nauki języka odbywa się przed komisją państwową powoływaną przez rząd stanu Kerala i Mahatma Ghandi University w Kottayam. 